\title{
EGFR NP_005219.2:p.N756_L760del
}

National Cancer Institute

\section{Source}

National Cancer Institute. EGFR NP 005219.2:p.N756 L760del. NCI Thesaurus. Code C98586.

A deletion of five amino acids from the epidermal growth factor receptor protein from the asparagine at position 756 through the leucine at position 760 . 